• e ISSN-0976-6855 | Visit us : www.researchjournal.co.in

\title{
Population dynamics of Aphis gossypii Glover on coriander in relation to biotic and abiotic factors
}

\author{
AHEIBAM RANILA, M.K. KANANI, J.B. BHUT* AND P.K. BORAD
}

Department of Entomology, B.A. College of Agriculture, Anand Agricultural University, ANAND (GUJARAT) INDIA

\section{ARITCLE INFO}

Received : 02.07 .2014

Revised : 11.09 .2015

Accepted : 25.09.2015

\section{KEY WORDS :}

Aphis gossypii, Population dynamics, Biotic - abiotic factors, Coriander

*Corresponding author:

Email: jignesh1315@gmail.com

\begin{abstract}
Field experiment was conducted on population dynamics of Aphis gossypii Glover on coriander (Gujarat coriander 2) in relation to biotic and abiotic factors during winter season of 2011-12 and 2012-13. Incidence of aphid on coriander started from $3^{\text {rd }}$ week of December $\left(51^{\text {st }} \mathrm{SMW}\right)$ and continued till $1^{\text {st }}$ week of March $\left(10^{\text {th }} \mathrm{SMW}\right)$ with a peak level during $5^{\text {th }}$ week of January $\left(5^{\text {th }} \mathrm{SMW}\right)$. Minimum and mean temperature had highly significant negative association with aphid incidence during first year, whereas nonsignificant negative correlation with the pest activity during second year. The morning vapour pressure had significant negative relationship with A. gossypii during first year and non-significant negative association during second year. Remaining all the tested meteorological parameters showed non-significant relationship with aphid population on coriander crop during both the years. The biotic factors, viz., coccinellids and syrphids as well as their cumulative numbers showed highly significant positive correlation with aphid population during both the years.
\end{abstract}

How to view point the article : Ranila, Aheibam, Kanani, M.K., Bhut, J.B. and Borad, P.K. (2015). Population dynamics of Aphis gossypii Glover on coriander in relation to biotic and abiotic factors. Internat. J. Plant Protec., 8(2) : 372-374. 